\title{
Boron deficiency in sugar cane, oil palm and other monocotyledons on volcanic soils of Ecuador
}

\author{
D. Tollenaar
}

Merellaan 8, Bilthoven, the Netherlands

Received 15 May 1968

\section{Summary}

Several monocotyledonous crops such as bananas, maize, sorghum, oil palm and sugar cane growing on volcanic soils of Ecuador were found to be affected by B deficiency. This indicates the severity of the B deficiency problem of these soils.

The first clear case of $\mathrm{B}$ deficiency in sugar cane plantations was reported. White striping of oil palm leaves was shown to be related to the same deficiency.

Soil analysis, leaf analysis and symptoms were evaluated as diagnostic methods. Boron needs of different plant species and even of cultivars differ so much that soil analysis is not able to give more than a general orientation. Thus, in the young volcanic soils of Ecuador, with a content of $0.25 \mathrm{ppm}$ water-soluble B, many crops will suffer from B deficiency, whereas with $0.5 \mathrm{ppm}$ or more it will hardly ever occur. Leaf analysis of cacao proved to be misleading, as no positive correlation was found to exist between the occurrence of $B$ deficiency and the $B$ content of the leaves. Although fertilizer field trials may furnish the clear proof and are also able to bring out nonsymptomatic deficiency (hidden hunger), their applicability is very restricted. Hence, visual symptoms remain essential for diagnosis of $\mathbf{B}$ deficiency.

In a B-deficient area the use of low B-requiring, local cultivars is of great importance. When B deficiency becomes apparent, it is not justified to await the result of fertilizer experiments. Preliminary control measures should be taken without delay, for B deficiency induces the formation of degenerated tissue which often results in unrepairable damage. Perennial crops developing boron deficiency symptoms should get an application of $40-100 \mathrm{~kg}$ of a $10 \%$ boron silicate frit per ha. This frit releases boron gradually, thus preventing leaching and overdosing.

\section{Introduction}

After the discovery of severe B deficiency in cacao plantations on young volcanic soils in Ecuador (Tollenaar, 1966), a survey was carried out in this area which revealed that even the generally low B-demanding monocotyledons were affected by B deficiency.

\section{Boron deficiency in Zea mais and Sorghum}

Boron deficiency symptoms of maize and other cereals are well-known from experimental studies on B-free media (van Overbeek, 1934; Löhnis, 1940; Bussler, 1962). 


\section{TOLLENAAR}

In 1966 similar deficiency symptoms in maize were observed in an area of Hacienda Pate where cacao had previously been eradicated by B deficiency. The young maize leaves were excreting a liquid from their upper leaf surfaces and showed white stripes. Developing leaves bulged into a loop before forcing themselves out of the sheaths, while the last leaves often showed torsion and never unfolded fully. Plumules and

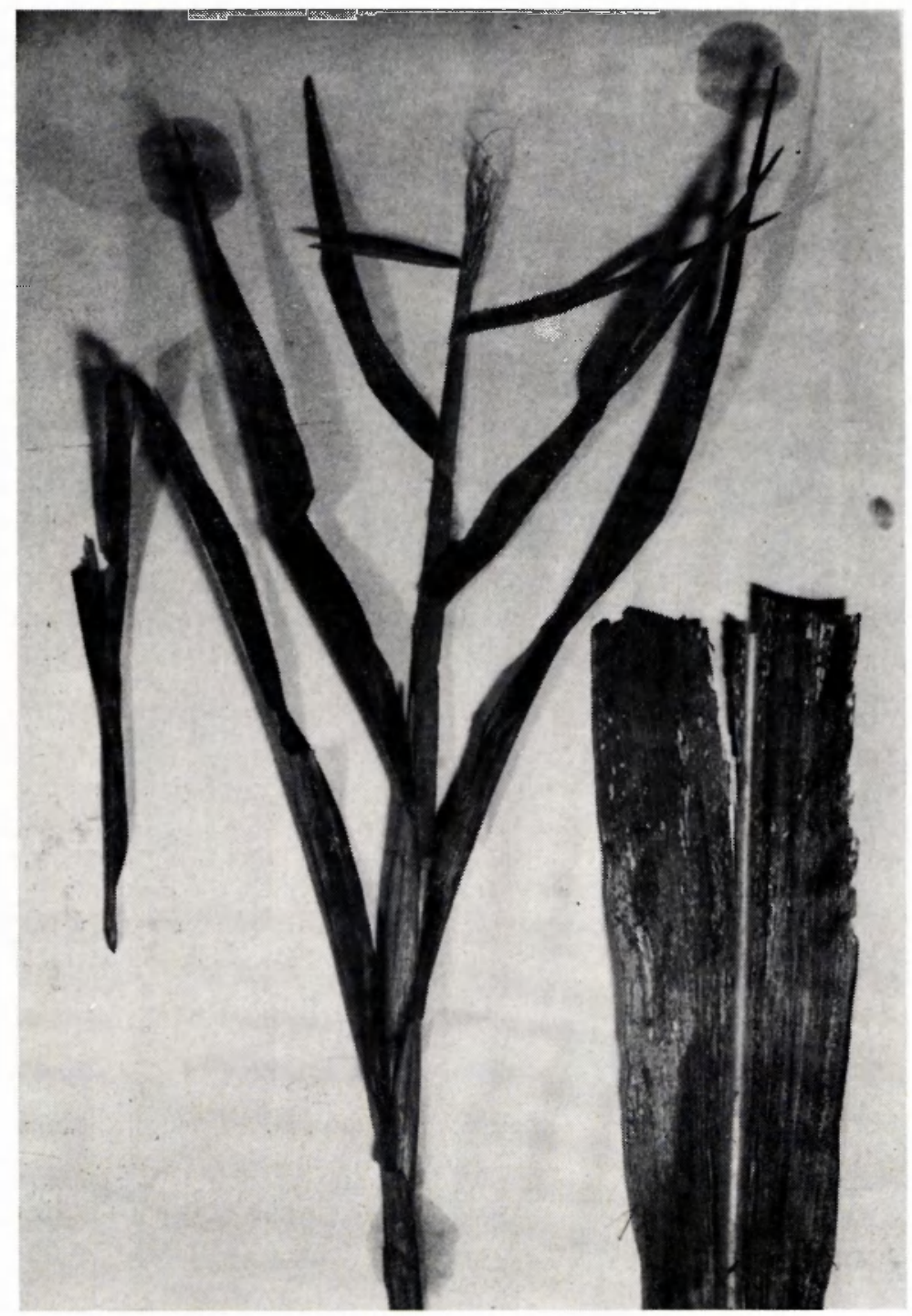

Fig. 1 B-deficient maize at Hacienda Pate. At right: part of lower leaves with white striping. At left: top of same plant with sterile plumula and sterile cob. The leaves are thick and curling and they have difficulties of unfolding 
ears varied from completely sterile to fully developed (Fig. 1). All these symptoms were more marked on new tillers. The water-soluble $\mathbf{B}$ content was at a depth of $0-20 \mathrm{~cm}: 0.16 \mathrm{ppm} ; 35-50 \mathrm{~cm}: 0.14 \mathrm{ppm}$; and $80-100 \mathrm{~cm}: 0.03 \mathrm{ppm} .{ }^{1}$

In the same year, identical $B$ deficiency symptoms were observed in large maize fields at Hacienda Clementina. Here it occurred particularly on eroded and on sandy strips. Sorghum grown in this area showed white striping of the leaves. Grossenbacher and Livingstone (1936) obtained the same sympioms in sorghum grown on B-free media. Along overflowing river banks where new silt had been deposited, B deficiency was absent. The water-soluble B content ascertained at 22 locations in this area (Fredriksson, 1962) showed a rapid decrease with depth. At a depth of only $20-30 \mathrm{~cm}$ $50 \%$ of the soil samples already contained less than $0.20 \mathrm{ppm}$ of water-soluble B.

\section{Boron deficiency in Saccharum officinarum}

Symptoms of B deficiency in sugar cane are known from pot trials (van den Honert, 1932; Martin, 1934; Evans, 1955; Malavolta et al., 1962; Hughes et al., 1964) and they are similar to those in cereals, viz white, longitudinal striping of leaves, leaf torsion and moisture excretion on the upper leaf surfaces. In an advanced state of disease leaves become short, narrow, distoried and chlorotic which is followed by the death of the growing point of the plant.

The symptoms of $\mathbf{B}$ deficiency have never been reported before from field plantations of sugar cane. In 1966 I found these typical symptoms in sugar cane throughout the young volcanic Riverine Belt, from Quininde in the north to Maravilla in the south, a distance of more than $250 \mathrm{~km}$. Near Quininde, near Santo Domingo and at Hacienda Pate the symptoms were very marked in an unknown cultivar of sugar cane, grown for private use on non-irrigated spots and harvested year after year without replanting. The laminae were full of longitudinal white stripes, which were sometimes arranged in chains of innumerable small white lines while in other parts they appeared as vague white streaks (Fig. 2). Cracks were often formed. In older leaves the colour of the stripes turned into brown. The same type of necrotic tissue appeared in the midribs and stalks. Young leaves often had difficulties in unfolding. Their leaf edges curled and leaf strips tore loose while the upper leaf surfaces bleeded. New tillers developed deficiency symptoms in a most severe way. They remained short and distorted and as soon as growth ceased, the growing point would die (Fig. 3).

At Hacienda Pate an affected sugar cane plot was observed regularly after the addition of $\mathrm{B}$ frit and it was noted that the abnormalities disappeared. The water-extractable B content of the soil in that plot - before B frit application - was $0.15 \mathrm{ppm}$ at $0-20 \mathrm{~cm}$ depth, $0.16 \mathrm{ppm}$ at $30-50 \mathrm{~cm}$ and $0.06 \mathrm{ppm}$ at $80-100 \mathrm{~cm}$. At Hacienda Clementina, one year old plots of sugar cane clones (Azul Casa Grande, POJ 2714, POJ 2878, POJ 3016, Canal Point, Clewingston and old Barbados clones) all showed the typical symptoms of B deficiency as described above. Already at the age of four months the striping of the leaves started to develop.

The sugar cane plantations of Ingenio Valdez and San Carlos only showed some B deficiency symptoms at locations that could not be irrigated and in older ratoon crops.

1 With exception of the soil samples from Hacienda Clementina, all leaf and soil analyses referred to in this paper were carried out by the Soils Laboratory of the Royal Tropical Institute in Amsterdam. 


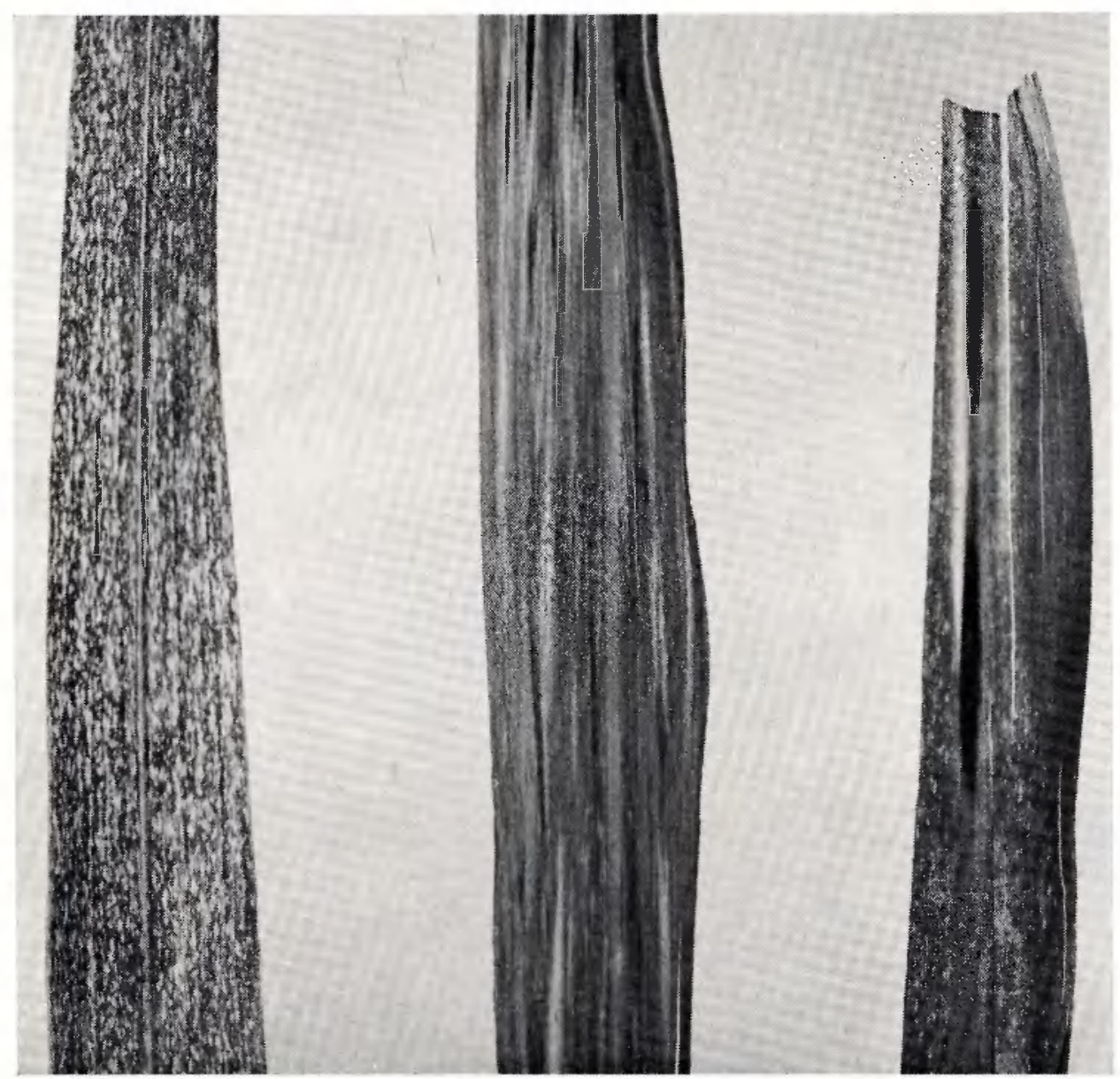

Fig. 2 B-deficient sugar cane near Santo Domingo de los Colorados. At left: lamina with innumerable short, white stripes. At right and in the middle: laminae with long, vague, white stripes and longitudinal cracks. White colour here and there turns into brown, necrotic tissue

\section{Boron deficiency in Elaeis guineensis}

In oil palms this deficiency is common in Southern Congo and in Malaya and recently it was also reported from Colombia (Ollagnier, 1964). Kovachich (1952a, 1952b, 1953) described a disease of oil palms in S. Congo, of which Ferwerda (1954) and Broeshart et al. (1957) proved experimentally that its cause was B deficiency. They induced the disease in healthy looking palms by fertilizer applications of $\mathrm{N}, \mathrm{P}, \mathrm{K}, \mathrm{Ca}$, $\mathrm{Mg}$ and their combinations, but when in addition $\mathrm{B}$ was supplied the trouble disappeared. This same induction of $\mathbf{B}$ deficiency by applying fertilizers without $\mathbf{B}$ is known from sugar beet and from cacao (Tollenaar, 1966).

The above mentioned authors described the symptoms as follows. Symptoms started 


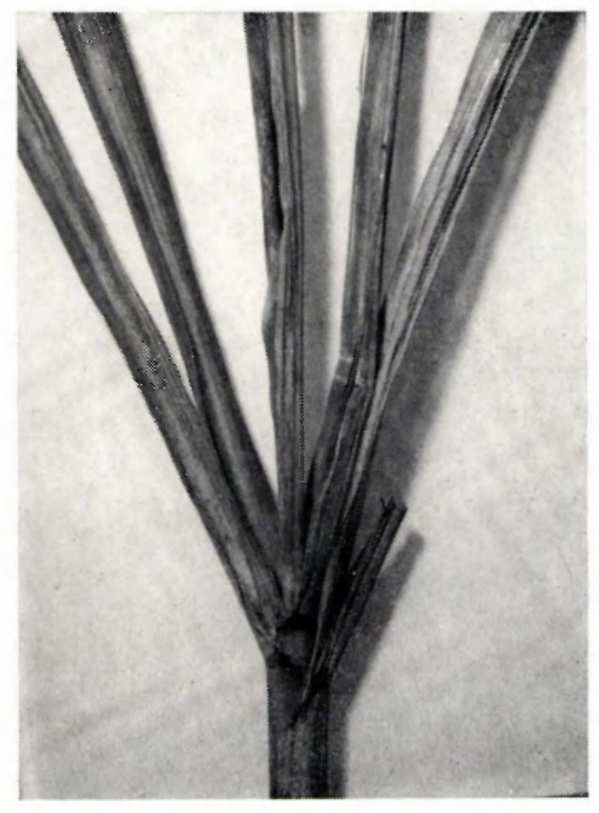

Fig. 3 Young tiller of B-deficient sugar cane at Hacienda Pate. Stalks are brown and necrotic. Leaves are narrow and thick and have white stripes. They hardly unfold and remain clustered. Photo: Royal Tropical Institute, Amsterdam)

with malformation of the pinnae, viz 'hooking', necrosis, torsion and a reduction in size ('little leaf'). Subsequently, abnormal inflorescenses were formed with a high percentage of aborted fruit (sterility). In the final stage of the disease, the growing point died (rot of the central spear and bud). Sometimes a temporary recovery occurred which was usually followed again by a more serious degeneration. The trouble started at the beginning of the productive period. Dry weather and impoverished soil favoured its appearance.

A new oil palm plantation, Hacienda Oleaginosas near Santo Domingo de los Colorados, developing beautifully at first, showed in 1964, when the oldest palms were 4 years old, scattered trees with white striped and hooked pinnae. Two years later this plantation was in a bad state and on the slopes palms were already dying. The leaf canopy as a whole looked unhealthy and poor. There was reduced fruit-set and the production had begun to drop. As will be described, it was experimentally proven that the cause was B deficiency. In contrast to the symptoms of B deficiency described by Ferwerda (1954), the most striking phenomenon here was white striping of the leaves, which later turned into yellow and brown. The difference observed in symptomatology may be due to the different cultivars used. The seed used at Hacienda Oleaginosas came from Chemara, Malaya, and according to Werkhoven (1965) white striping due to B deficiency is there of common occurrence. Besides striping I observed 'hooking', reduction of size and malformation of the pinnae. In an advanced state of the disease the leaves did not unfold, since the pinnae had already turned necrotic in an early stage of development (Fig. 4). The leaves, thus developing with increasing difficulty, clustered in the crown and rotting of the central spear soon followed. The condition of the oldest palms looked so alarming that there seemed no time left to study the cause of the disorder first in field trials. Because the symptoms were typical for B deficiency (sterility phenomena and dying of the growing point, 
D. TOLLENAAR

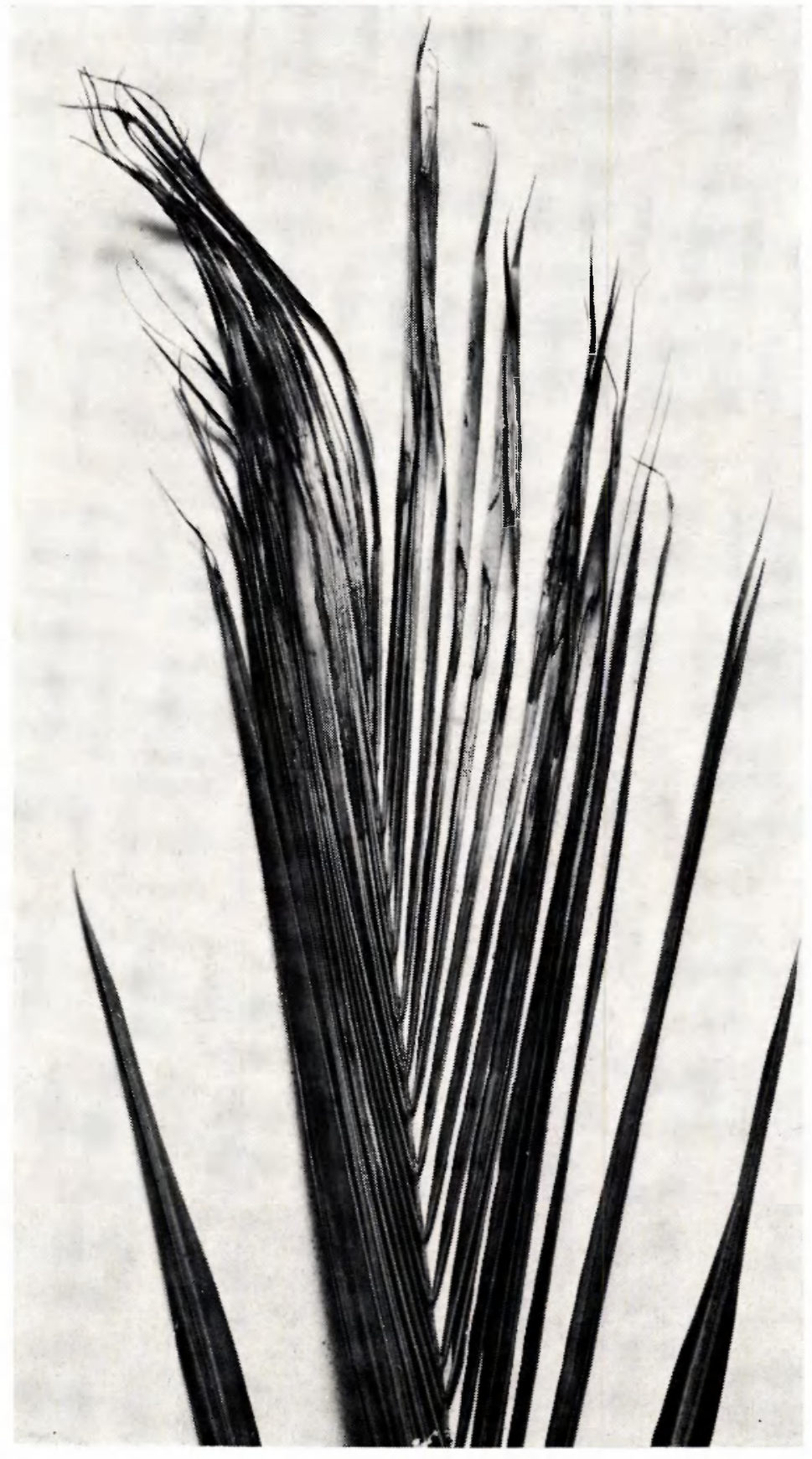

Fig. 4 B-deficient oil palm leaf at Hacienda Oleaginosas. Leaf top does not unfold, the right part was artificially opened in order to show brown, necrotic, not fully developed pinnae 
at the beginning of the productive stage) and because cacao at surrounding farms had died from this malnutrition, it was decided to apply without delay $150 \mathrm{~g}$ of a $10 \% \mathrm{~B}$ glass frit per tree. The frit was applied in a circle of 75 to $100 \mathrm{~cm}$ from each tree and superficially worked under the soil. A few hundred palms were left untreated as a check. Already two months after this application newly developing leaves of the fertilized plants had no more white stripes. Four months after the treatment the difference between the treated and untreated palms was very striking. The former had healthy green leaves again and their size had increased considerably. This remarkably rapid response indicated how short in supply of $B$ the palms were in this stage of their development.

\section{Bananas: no deficiency symptoms, but a response to $B$ applications}

Carperitier and Martin-Prével (1965) and Norton (1965) found in pot experiments that typical white striping of the banana leaves occurred when B was eliminated from the fertilizer mixture. I have never observed these sympioms in any banana plantation in Ecuador. Yet, spraying of $8 \mathrm{~kg}$ of Solubor per ha at Hacienda Pate resulted soon in an increase in the number of green leaves per plant (Tollenaar, 1966). This effect lasted for about 12 months and it was followed 12 to 20 months after spraying by a production rise of approximately $15 \%$ as compared with the untreated area. After two years the effect of this spray had ceased completely and then the same treatment was repeated which again resulted in a quick increase in green leaf number compared with untreated bananas.

The water-soluble B content of the soils of this trial area was similar to that found in other parts of this zone, viz $0.26 \mathrm{ppm}$ in the upper humus layer and only 0.06 ppm at 30-40 cm depth. The fact that bananas do not show visual disorders on these soils as so many other crops were found to do (avocado, cacao, chinese cabbage, citrus, clover, coffee, cotton, mango, oil palm, trefoil, sorghum, sugar cane) indicates that they are very low B-demanding, which makes them a suitable crop for the Riverine Belt.

\section{Why is boron deficiency so common in young volcanic Andes deposits?}

A wide range of crops, even monocotyledons as was shown here, are affected by $B$ deficiency on the young volcanic soils of Ecuador. There is also evidence that in other parts of the Andes many crops often suffer from B deficiency. It was reported from Colombia (oil palm; Ollagnier, 1966), Peru (Cabello and Ortiz report in 1966 that in Cuzco Province 98,5\% of the soils studied showed B deficiency), N.W. Argentine (citrus) and Chile (grape, olive and pine). The main factors which make $B$ deficiency so common, persistent and difficult to combat are:

1. Thick, loose layers of ash, especially when situated on ridges and slopes, are subject to intensive leaching by heavy tropical rains. No return flow takes place during the dry season because of the low watertable.

2. The young volcanic ash is hardly weathered and consequently there is no clay mineral adsorption complex to retain $B$ for plants. Humus is the only alternative material to adsorb B. But under hot, tropical conditions, humus is scarce and limited to the upper soil layer and subject to removal by erosion and sun burning. 
3. The abnormally high $\mathrm{Ca}$ content of these soils aggravates $\mathrm{B}$ deficiency.

4. Large amounts of mobile $\mathrm{Al}$ in these soils (20 to 30 times of normal) will reduce the uptake of $B$, as is known from experience elsewhere.

5. The hot, prolonged dry seasons stimulate outbreaks of $\mathbf{B}$ deficiency.

6. Due to absence of wind in Ecuador there is no $B$ transport by means of the aerosol from the sea.

7. The configuration of the Andes restricts in a large part of this area the overflow of rivers, thus preventing the deposition of new silt and humus particles.

Throughout the Riverine Belt B deficiency was absent on overflowing river banks in the low lands (near Santo Domingo, Quevedo, Vinces, Catarama, Hacienda Clementina). Cacao, for example, showed hardly any signs of B deficiency on the Quevedo river bank in an area called ' $\mathrm{La}$ Isla' near the experimental station of Pichilingue, whereas it suffered heavily on the surrounding hills. Soil analyses showed corresponding differences in water-soluble B content (Table 1).

Table 1 Water-soluble $B$ content of the soil and the occurrence of $B$ deficiency in cacao at Pichilingue Experimental Station at Quevedo

\begin{tabular}{cccc}
\hline Site & $\begin{array}{c}\text { Condition of the } \\
\text { cacao trees }\end{array}$ & Boron (ppm) \\
\cline { 3 - 4 } & top soil & sub soil \\
$\begin{array}{l}\text { La Isla, bank of the } \\
\begin{array}{c}\text { Quevedo River } \\
\text { Surrounding high land }\end{array}\end{array}$ & B-deficient & 0.35 & $0.17(60-80 \mathrm{~cm})$ \\
& & 0.09 & $0.11(30-40 \mathrm{~cm})$
\end{tabular}

\section{Diagnosis of boron deficiency}

Soil analysis. A recent compilation (Chapman, 1966) indicates that many crops are affected by B deficiency when the water-soluble B content of the soil falls below $0.5 \mathrm{ppm}$. However, this critical level can only be of value as a general orientation, because it considerably varies with the plant species and even with the cultivars of one species (Tauböck, 1943; Tollenaar, 1966). It also varies with the weather, the $\mathrm{pH}$ and the $\mathrm{Ca}$ content of the soil; for beet, for example, this critical level is higher in dry years and in alkaline soils (Lehr and Henkens, 1959).

According to my experience, in the young volcanic soils of Ecuador B deficiency can be expected to occur frequently when the water-soluble $B$ content of these soils falls below $0.25 \mathrm{ppm}$, whereas it will be absent above $0.5 \mathrm{ppm}$.

Foliar analysis. Foliar analysis has become a popular method for diagnosis of mineral deficiencies, but in the case of the severe B deficiency of cacao in Ecuador, foliar analysis turned out to be misleading. Here no correlation was found to exist between the observed disorder and the B content of cacao leaves (see Table 2), although sampling instructions were carefully observed.

The erroneous conclusion concerning the nature of the disorder thus led to a delay of the highly needed B applications and to the death of hundreds of hectares of cacao plantations. This delay proved to be so serious because in the course of one 
BORON DEFICIENCY IN SUGAR CANE, OIL PALM, ETC., ON VOLCANIC SOILS OF ECUADOR

Table 2 Total B content (ppm) in leaves of healthy and B-deficient cacao

\begin{tabular}{|c|c|c|c|}
\hline Site & Cacao cultivar & $\begin{array}{c}B \text { content } \\
\text { in ppm } \\
\text { (last flush) }\end{array}$ & $\begin{array}{c}\text { B content in ppm } \\
\text { (last flush } \\
\text { but one })\end{array}$ \\
\hline \multicolumn{4}{|l|}{ 1. Healthy plantations } \\
\hline 1. Trinidad & ICS 1 & 33.34 (dupl.) & 26.31 (dupl.) \\
\hline 2. Machala (Ecuador) & Scavina hybr. & & \\
\hline 3. Trinidad & Scavina hybr. & 27.28 (dupl.) & 26.31 (dupl.) \\
\hline 4. Pichilingue & Scavina hybr. & 30 & 31 \\
\hline \multicolumn{4}{|c|}{ II. Deadly diseased plantations ( $B$ deficiency) } \\
\hline 5. Pate, spot A & ICS 1 & 37 & 35 \\
\hline 6. Pate, spot A & Scavina 6 & 42 & 42 \\
\hline 7. Pate, spot $\mathrm{C}$ & Scavina hybr. & 34 & 31 \\
\hline 8. Pate, spot D & Scavina hybr. & 28 & 31 \\
\hline \multicolumn{4}{|c|}{ III. Experiment with $B$ frit fertilizer } \\
\hline Pate, spot A & $\begin{array}{l}\text { Scavina } 6 \\
\text { (fertilized) }\end{array}$ & 50 & - \\
\hline Pate, spot A & $\begin{array}{l}\text { Scavina } 6 \\
\text { (not fertilized) }\end{array}$ & 47 & 一 \\
\hline
\end{tabular}

year such a basic part of the tissues of branch and root system had become degenerated that recovery of the plants was then no longer possible.

The fact that often no positive correlation is found to exist between certain minor element deficiencies and the content of the relative elements in the plant tissues has been observed by several authors. Müller (1959) mentioned this in connection with coffee. In oats, Jones (1957) found that the lowest content of $\mathrm{Mn}$ in straw and grain coincided with maximum yield, whereas the Mn content of stunted, Mn deficient plants was highest. Similar results were published by Piper (1942) and Steenbjerg (1951) in connection with copper deficiency and by Ulrich (1952) regarding zinc deficiency. The role of several minor elements is essential but limited to special functions in certain tissues and often even restricted to a critical period in their development. For example, $B$ has a function in active meristematic tissues and we should not be surprised that an analysis of the full-grown leaf is no adequate method to trace $B$ deficiency.

Symptoms. Due to the unreliability of chemical methods, visual symptoms remain essential for the diagnosis of minor element deficiencies in plants. Regular observation of a developing crop is necessary for the timely discovery of deficiencies. This requires much field experience, but no chemical routine analysis is able to replace visual diagnosis.

With boron an overlapping of deficiency and toxicity symptoms sometimes occurs. If this causes doubt, then the water-soluble $B$ content of the soil is able to decide whether toxicity or deficiency is involved.

Field trials. A conclusive answer with regard to minor element deficiencies may be expected from fertilizer field trials. A thorough production analysis of a field trial with many fertilizer combinations will also enable to demonstrate hidden hunger, like in the case of $\mathbf{B}$ deficiency without visible symptoms in bananas at Hacienda Pate. 
Yet, the applicability of the results of such field trials is limited. Furthermore field trials are laborious and expensive and they need a rather extensive, uniform plantation area. They also take much time, often more than there is available in case of an acute deficiency. Hence, for the diagnosis of minor element deficiencies visual symptoms remain essential.

\section{Control of boron deficiency}

Control of B deficiency is no easy matter. On the one hand it is urgent to supply sufficient B fertilizer soon after its appearance, on the other hand risks of overdosing exist. Furthermore, in order to avoid overdosing the B fertilizer should be broadcasted evenly which poses practical problems with small quantities, such as are supplied in the case of minor elements. Foliar spraying of perennial crops does not present a solution, as this proved not to satisfy the plant's needs of boron when growing under severely B-deficient conditions, such as prevail in the Riverine Belt.

According to my experience in the Riverine Belt an application of $40-100 \mathrm{~kg}$ of a $10 \%$ boron silicate frit per ha to perennial crops is the first measure to be taken immediately. Concurrent trials with different fertilizer combinations and various amounts of $B$ frit should be set up.

The advantages of a boron silicate frit under such conditions were described by Holder and Engel (1958), Middelburg and van Baren (1962), Page and Cooper (1955) and Rhoads et al. (1956). Because the frit releases its B gradually this prevents overdosing and reduces leaching An amount of $100 \mathrm{~kg}$ can therefore be applied without dangerous effects and such an amount also enables a rather regular distribution. Moreover, by using finer or coarser silicate glass, the release of $\mathbf{B}$ can be increased or decreased respectively. In humid, tropical regions the frit to be applied should be coarser than in a moderate climate.

Finally, if an area is known for its B deficiency the use of low B-demanding cultivars is essential. As a rule local cultivars will be preferable, since through natural selection they will be adapted to a low B content of the soil.

\section{References}

Broeshart, H., Ferwerda, J. D. \& Kovachich, W. G., 1957. Mineral deficiency symptoms of the oil palm. Pl. Soil 8: 289-300.

Bussler, W. A., 1962. Boron deficiency in Maize. Mitt. deutsch. Landw. Ges. 77: 1110-1112.

Bussler, W., 1964. Die Bormangelsymptom und ihre Entwicklung. Z. PflErnähr., Dïng., Bodenk. 105: 113-116.

Cabello, J. K. \& Ortiz, D. S., 1966. Boron deficiency in soils of Cuzco Province. Boln Soc. quim. Perú 32: 94-106.

Chapman, H. D., 1966. Diagnostic criteria for plants and soils. University of California, Division of Agricultural Science, p. 793.

Charpentier, J. M. \& Martin-Prével, P., 1963. Carences en oligoéléments chez le bananier. Fruits 20: $521-537$.

Evans, H., 1955. Studies in the mineral nutrition of sugar cane in British Guiana. Trop. Agric., Trin. 32: 315-316.

Ferwerda, J. D., 1954. Boron deficiency in the Kassai Region of the Belgian Congo. Nature $173: 1097$.

Fredriksson, L., 1962. Preliminär sammanställing av resultaten frän undersöckninger rörande växtnäringsförhällandend i marken på Hacienda Clementina. Unpublished report. 
Grossenbacher, R. A. \& Livingstone, B. E., 1936. Cryptotrophic malnutrition in sorghum in solution cultures. Am. J. Bot. 23: 588-603.

Holden, E. R. \& Engel, A. J., 1958. Boronsilicate glass as continuing source of boron for alfalfa. Agr. Fd. Chem. 6: 303-305.

Honert, T. H. van den, 1932. Onderzoekingen over de voedselphysiologie van het suikerriet. Meded. Proefstn Java-SuikInd. 23 : 1539-1606.

Hughes, G. G., Abbot, E. V. \& Wismer, C. A., 1964. Sugar cane diseases of the world. Vol. 2, p. 202-205. Amsterdam, Elsevier.

Jones, L. H. D., 1957. The relative content of manganese in plants. Pl. Soil 8: 328-336.

Koronovski, P., 1961. Morphologische Veränderungen in Mais und andere Getreidearten bei Bormangel. Z. PflErnähr., Düng., Bodenk. $84: 25-39$.

Kovachich, W. G., 1952a. Abnormal roots in oil palms in the Belgian Congo. Trop. Agric., Trin. 29: 29-34.

Kovachich, W. G., 1952b. Little leaf disease of the oil palm in the Belgian Congo. Trop. Agric., Trin. 29: 105-114.

Kovachich, W. G., 1953. Little leaf disease of the oil palm in the Belgian Congo II. Trop. Agric., Trin. 30: 61-69.

Lehr, J. J. \& Henkens, C. H., 1959. Threshold values of boron contents in Dutch soils in relation to boron deficiency in beet, in: Transactions of the World Congress on Agricultural Research, Rome, p. 1397-1407.

Löhnis, M. P., 1940. Histology of boron deficiency in plants. Meded. LandbHoogesch. Wageningen 44-3: 3-36.

Malavolta, E., Haag, H. P., Mello, F. A. F. \& Braskl, Sobro, 1962. On the mineral nutrition of some tropical crops. International Potash Institute, Berne, p. 155.

Martin, J. P., 1934. Boron deficiency in sugar cane. Hawaii. Plrs' Rec. 38: 95-107.

Middelburg, H. A. \& Baren, H. van, 1962. Bemesting met borium in fritvorm. Landbouwk. Tijdschr. $74: 865-871$.

Müller, L., 1959. La aplicación diagnostica foliar en el cafeto para un mejor fertilización. Turrialba 9: 110-122.

Norton, K. R., 1965. Boron deficiency in bananas. Trop. Agric., Trin. 42: 361-365.

Ollagnier, M., 1966. La plantación de palmera de aceite de San Alberto. Oléagineux 21: 575-578.

Overbeek, J. van, 1934. Die Symptome des Bormangels bei Zea mais. Meded. phytopath. Lab. Willie Commelin Scholten 13: 29-33.

Page, N. R. \& Cooper, H. P., 1955. Less soluble boron compounds for correcting nutritional deficiencies. Agr. Fd Chem. 3: 222-225.

Piper, C. S., 1942. Investigations on copper deficiencies in plants. J. agr. Sci. 32: 143-178.

Rhoads, W. A., Wallace, A. \& Romney, E. M., 1956. A slowly soluble source of micro-nutrients for plants. Soil Sci. 81: 359-371.

Steenbjerg, F., 1951. Yield curves and chemical plant analyses. Pl. Soil 3: 97-109.

Tauböck, K., 1943. Ueber physiologische Rassen mit verschiedenem Boranspruch. Bot. Arch. 44: $52-71$.

Tollenaar, D., 1966. Boron deficiency in cacao, bananas and other crops on volcanic soils of Ecuador. Neth. J. agric. Sci. 14: 138-151.

Ulrich, A., 1952. Physiological bases for assessing the nutritional requirements of plants. A. Rev. Pl. Physiol. 3: 207-228.

Werkhoven, J., 1965. The manuring of oil palms. Green Bull. 19. Verlags-Ges. f. Ackerbau, Hannover, p. 52. 